Г. Г. Демиденко

\title{
СТРУКТУРНО-СЕМАНТИЧНІ ОСОБЛИВОСТІ МІМІЧНИХ ФРАЗЕОЛОГІЗМІВ
}

Демиденко Г. Г. Структурно-семантичні особливості мімічних фразеологізмів.

У статті йдеться про структурно-семантичні особливості одного з різновидів паралінгвістичних фразеологізмів, зокрема мімічних, у яких зафіксовано мовний досвід народу, стереотипність його мислення, відображено емоційно-вольову сферу життя, інакше кажучи, закодовані етнопсихологічні характеристики; мімічні фразеологізми диференційовано відповідно до особливостей погляду, виразу очей, мімічних реакцій, у яких беруть участь окремі частини обличчя, а також дій, що виражають фізіологічні зміни обличчя.

Ключові слова: паралінгвістичний фразеологізм, мімічний фразеологізм, мімічна реакція, фізіологічні зміни.

Демиденко А. Г. Структурно-семантические особенности мимических фразеологизмов.

В статье рассматриваются структурно-семантические особенности одного из разрядов паралингвистических фразеологизмов, а именно мимических, в которых зафик- 
сирован языковой опыт народа, стереотипность его мышления, отображена эмоционально-волевая сфера жизни, закодированы этнопсихологические характеристики; мимические фразеологизмы анализируются в соответствии с особенностями взгляда, выражения глаз, мимических реакций, в которых участвуют отдельные части лица, а также действий, связанных физиологическими изменениями лица.

Ключевые слова: паралингвистический фразеологизм, мимический фразеологизм, мимическая реакция, физиологические изменения.

Demidenko A. H. Structural and semantically peculiarities of the mimical set expressions.

Struktural and semantical peculiarities of one of the types of paralinguistic set expressions are examined in this article. Specifically the peculiarities of the mimical set expressions are examined; language experience of the nation, stereotype of its mentality were fixed in the mimical set expressions; emotional and power side of the life were reflected; ethnopsyhological character were coded in the mimical set expressions.

The mimical set expressions are analysed according to the peculiarities of the look, the expression of eyes, mimical reactions, where separate parts of the face are taken part; the actions which demonstrate the physiological changes of face.

Key words: paralinguistical set expression, mimical set expression, mimical reaction, physiological changes.

Мімічні реакції та дії в сучасній мовознавчій науці розглядаються як невербальні компоненти при безпосередньому контакті комунікантів. Автономне функціонування невербальних засобів наявне у трьох ситуаціях коли немає можливості використовувати вербальні засоби, коли через ті чи ті причини не можна послуговуватися мовним кодом для передачі інформації і в умовах адаптації до напруженої ситуації. Мабуть, що при автономному функціонуванні мімічні рухи та кінесеми повинні мати однозначну інтерпретацію. У самостійному режимі особливо активно функціонують погляд і поза - здавалося б, найменші за формою і змістом невербальні одиниці. Вони володіють складною структурою - передбачають безліч компонентів - обов'язкових і факультативних. Погляд передбачає розмір зіниці, спрямованість, відвертість, частоту моргання. Експерименти показали, що погляд функціонує більш активно під час слухання, а не мовлення; що складнішою є тема бесіди, то менш частотними є погляди і менше часу йде на фіксацію одного предмета. Окреслені проблеми поки що не стали об'єктом дослідження спеціальних грунтовних лінгвістичних наукових розвідок. До них звертаються здебільшого принагідно, зокрема й під час осмислення такого явища, як паралінгвістична фразеологія (Г. Крейдлін, В. Лабунська, А. Павлова, О. Селіванова, Л. Скрипник, В. Ужченко та інші).

Мета нашої статті полягає в тому, аби розглянути структурносемантичні особливості одного з різновидів паралінгвістичних фразеологізмів, зокрема мімічних.

Психологічна наука зауважує, що міміка та жести передають інколи значно більшу кількість інформації, ніж слова, або заперечують правдивість висловлювання. Фразеологізми на позначення мімічних процесів долучаються до загального масиву паралінгвістичних ФО та роблять акцент 
на емоційному стані людини в момент спілкування. Їх доцільно розподілити на три групи:

1) ФО, які характеризують особливості погляду, виразу очей;

2) стійкі сполучення, що називають мімічні реакції, дії, у яких беруть участь окремі частини обличчя (губи, рот, окремо вуха);

3) емоційно насичені фразеологізми на позначення мімічних дій, що виражають певні фізіологічні зміни рис обличчя.

Очі і вираз очей відіграють важливу роль не тільки в невербальному віддзеркаленні людських емоцій, але і в передачі іншої, у смисловому відношенні вельми різноманітної інформації. Сьогодні немає жодних сумнівів у тому, що в межах однієї культури й однієї мови жестів жести очей, або візуальні знаки, незмінні в тому сенсі, що мають у них постійне значення. Тому зростає інтерес до мови очей та до окулесики - науки про мову очей та інтерактивну візуальну поведінку людини. Важливим є співвідношення словесного та зорового коду інформації про світ, що потребує детального вивчення на тлі стійких висловів у мові.

Мімічні фраземи, що характеризують особливості погляду, виразу очей можна розглядати 3 кількох позицій: звернути увагу на емоційне забарвлення, спрямованість на певний об’єкт навколишньої дійсності, специфіку виразу очей, відповідно до анатомо-фізіологічних та рефлексивних особливостей, на певні психічні закономірності, на ситуативний характер зорової дії тощо. Звичайно, такий розподіл є досить умовним, однак допоможе детальніше, більш усвідомлено проаналізувати ФО цього типу.

Так, до першої групи, куди ми зараховуємо ФО, що характеризують особливості погляду, виразу очей відповідно до емоційного забарвлення та насичення, можемо віднести такі фразеологізми: глянути недобрим оком; гострий на око; очі великі; дивитися / глянути вовком; хазяйським оком; свіжим оком; неситим оком; вовчим оком; сизим оком; критичним оком; лихим оком тощо.

Фразеологізм глянути недобрим оком означає, за народними уявленнями, „Поглядом пошкодити, спричинити нещастя, принести кому-небудь горе, невдачу; зурочити". Вислів має внутрішньомотивований пізнавально оцінний зміст - $з$ одного боку, у ньому зафіксовано ставлення мовця до дійсності, ii оцінка в невербальному оформленні (оцінка самого погляду недобрим оком ), з іншого, - емоційна насиченість через переживання самої дії як наслідку впливу міфологічного світогляду і підсвідома віра в надприродне, магічну силу людського погляду.

Особливість фразеологізму хазяйським оком, що означає ,дивитися дбайливо, уважно, по-господарськи", полягає в характеристиці самого погляду. Українська людина є носієм відповідних ментальних рис, які певною мірою розглядаються через вплив виховних процесів та загальних закономірностей розвитку психіки: колективне підсвідоме та вплив соціально значущого виховного інституту визначають ії як працьовиту, таку, що пра- 
гне до самореалізації в цій праці, особливо на власній землі. Звідси ,законсервованість” вислову хазяйським оком - отже, це погляд господаря 3 позитивною емоційною налаштованістю на життя та роботу.

Відповідно до виразу очей та погляду через розуміння спрямованості на певний об’єкт визначаються ФО, які найбільше „вербально передають невербальну інформацію” про особливість комунікативної взаємодії між мовцями. До цієї групи належать такі фразеологізми: сковзати / сковзнути очима (поглядом); вести оком; грати очима; їсти очима (оком); колоти очима; липнути очима; обсипати поглядом; поглинати очима (поглядом, зором); ковзнути поглядом (очима); вбирати очима (в очі, поглядом); зміряти очима (оком, поглядом); [ніби] ловити очима (поглядом, зором); блудити очима (поглядом); пасти очима (оком, зором, поглядом) тощо. Вони побудовані здебільшого за моделлю: „дієслово + іменник „очі” („,огляд”) в орудному відмінку”.

Основними ознаками, що характеризують комунікативну поведінку очей, є напрям, або лінія, погляду, об’єкт погляду - „на що спрямований погляд" і тип погляду, тобто безпосередньо спосіб візуальної взаємодії. Крім того, у формулюванні правил поведінки очей важливими є такі параметри, як величина очей, їх рух, переміщення погляду з одного об'єкта на інший, тривалість погляду і візуального контакту.

Слово погляд, згідно з тлумаченням О. Урисон, означає “те невидиме, що людина випускає 3 очей, коли дивиться на що-небудь” [3, 23]. Він пов'язаний з відчуттями і думками людини, з іiі бажаннями і прагненнями, він виражає стан людини, інакше кажучи, за поглядом стоїть передовсім якась препозитивна структура, що характеризує людину.

Фразеологізм зміряти очима (оком, поглядом) означає „пильно, уважно оглянути кого-, що-небудь". Особливість такого погляду полягає в тому, що значення сталого вислову безпосередньо стосується умов комунікації та поведінки очей: зустрівши людину, яку тривалий час не бачив, або наштовхнувшись поглядом на людину (об'єкт) 3 незвичайним зовнішнім виглядом, зростом, статурою ми буквально „міряємо очима” зріст від голови до П’ят, оцінюємо масу, уважно роздивляємося вбрання і т. ін. Наприклад: Становий здивованим поглядом зміряв Семена від голови до n'ят, наче не сподівався такої упертості (М. Коцюбинський). Значення ж ФО колоти очима є негативно оцінним - ,уважно розглядати”, однак переважно підозріло, недоброзичливо, можливо навіть 3 докором. Сам процес коління, наколювання є фізіологічно неприємним для людини, викликає біль, звідси відчуття "колючого” погляду орієнтоване на внутрішній психологічний дискомфорт, ситуація спілкування характеризується як комунікативно невдала, регресивна. Наприклад: Врешті Лазар з'явився. Його обступили, питали, кололи очима (М. Коцюбинський).

Одним з видів пам'яті людини є зорова, пов'язана зі збереженням та відтворенням зорових образів. Стійкий вислів вбирати очима (в очі, погля- 
дом), а саме оглядаючи, сприймати, запам'ятовувати бачене, виник на основі фізіологічної потреби зберегти якомога з більшою кількістю деталей певний важливий для суб'єкта об'єкт спостереження, особливо якщо останній має для нього особистісне значення. Наприклад: Дорошенко вбирає поглядом простір лиману (О. Гончар). Для суб'єкта пізнання об'єкт набуває таких рис та властивостей, які сприяють кращому запам'ятовуванню за допомогою зорового аналізатора. Однак фразеологізм передає не просто зорове фіксування та процес запам'ятовування, у ньому закладено внутрішній сенс самого процесу - важливість, емоційна потреба „сфотографувати” очима особливість об'єкта, який і становить особисту цінність.

Фразеологізм сковзати очима (поглядом) визначає таку спрямованість на об'єкт, що має значення: „мимохідь дивитися на кого-, що-небудь”. Процес сковзання має свої значення; по-перше, це „рухатися по гладкій, слизькій поверхні, не відриваючись від неї”, по-друге, “легко, плавно переміщатися, злегка торкаючись поверхні чого-небудь”. Специфічність руху по слизькій поверхні зумовлює його швидкість та безперешкодність, однак семантика, закладена у $\Phi О, \epsilon$ не безпосереднім витлумаченням, а лише переймає основні ознаки руху і вкладає вже психічно мотивоване значення. Семантичною особливістю стійкого вислову $є$ те, що дія уточнюється прислівником мимохідь, тобто мимоволі, а значить, неусвідомлено, інколи навіть рефлексивно. Отже, це переміщення з одного предмета на інший чи вздовж одного предмета без затримок, швидкий погляд, розуміння якого здійснюється завдяки поєднанню особливості процесу сковзання як руху та особливості зорового сприймання об'єкта саме через неусвідомлені механізми.

Специфіку виразу очей з позицій анатомо-фізіологічних та рефлексивних особливостей можна визначити, дослідивши такі ФО: робити великі очі; лупати очима; в очах замигтіли [білі, веселі, грайливі] метелики; очі горять; очі бігають; очі світяться; опустити очі; кліпати очима; [аж] очі на лоб (на лоба) лізуть; [аж] очі обараніли; в очах жовтіє тощо. Ці фразеологізми ввібрали в себе досвід про людський організм, зокрема про фізіологічні процеси в зоровому аналізаторі. Під час впливу прямих сонячних променів на очі, людина їх прикриває, коли в око потрапляє пил та інші чужорідні тіла, вона починає кліпати. Крім цього, $є$ ще ряд процесів, які виникають при різних емоційних станах, мають свою специфіку вираження очима та поглядом на рівні відповідних реакцій. Наприклад, фразеологізм робити великі очі означає „виявляти подив, здивування”. Дійсно, під час психологічних станів на кшталт подиву, здивування, страху очі людини мають здатність збільшувати свій розмір. Це насамперед стосується зіниць, які при малому освітленні стають більшими, щоб пропустити якомога більше світла. Тому не дивно, що досвід людини про такі особливості зору став підгрунтям для оформлення фразеологізму.

У моменти переживання емоційних потрясінь, збентеження, відчуття сорому людина опускає очі вниз, нібито щоб уникнути зустрічі з поглядом 
співрозмовника, обірвати зорову комунікацію, тим самим зменшити свої переживання. ФО опустити очі [в землю, додолу] буквально і дає характеристику цим емоційним станам „відчувати незручність, сором, збентеження; дивитися вниз; засоромитися, знітитися". Значення фразеологізму неначебто „лежить на його поверхні”, однак має узагальнювальний характер. За таким же принципом утворена ФО в очах жовтіє. Вона означає, що „хто-небудь утрачає здатність нормально бачити, комусь стає погано від фізичного болю, утоми, хвилювання". Зорове сприйняття має найбільше значення в житті людини, а очі, як його головний орган, та пов'язані з ними відділи мозку є найскладніше утвореними в порівнянні з іншими аналізаторами. Фізіологічно процес погіршення зору (мається на увазі розмите, нечітке сприйняття об'єктів навколо, надмірна чутливість до світла та ін.) є наслідком ускладнень у роботі нейтронних зв'язків, безпосередньо рецепторів, рецепторних полів або інших змін. Звичайно, дослідження таких порушень функціонування нервової системи людини, зорового апарату вимагають грунтовних знань з медицини, зокрема неврології. Однак стан, до якого призводять будь-які порушення, відомий усім. Тому при оцінці певної ситуації спілкування „фразеологічними засобами” відбувається порівняння характеру емоцій у певний момент з аналогічними станами, чи то психологічними, чи то психофізіологічними, з минулого особистісного досвіду. Таке зіставлення вимагатиме доцільності використання ФО: людина може бачити нормально, нормально аналізувати інформацію, однак іiі внутрішній емоційний стан буде „спотворювати” об'єктивні сигнали навколо, викликати стан запаморочення, утрати зору. Тобто в основі ФО знову ж таки фізіологічне відчуття, яке за конкретних умов набуває переносного значення.

Звертаючи увагу на певні психічні закономірності, на ситуативний характер зорової дії, варто виокремити такі ФО: гострити очі; відкрито глянути у вічі; заплющувати очі; [аж] піт очі заливає; відводити очі; зривати очі; відривати очі (погляд); очі розбігаються; очі припали; впиватися очима (поглядом, зором) тощо. На нашу думку, вони умовно побудовані за зразком „стимул - реакція” у психологічному плані, у змістовому плані характеризуються певною результативністю.

Фразеологізм відводити очі означає ,1) переставати дивитися на когонебудь; намагатися не дивитися на кого-небудь; уникати зустрічі очима 3 кимось; 2) навмисне відволікаючи увагу від кого-, чого-небудь, обдурювати когось”. Зазвичай людина відвертає очі чи погляд, щоб обірвати комунікацію, мотивуючи це певним небажанням спілкуватися з кимось, страхом, відразою, соромом, апатичним станом тощо. На місці безпосереднього жесту, навіть руху очима, характеризуючи таку реалію в міжособистісному спілкуванні як „не хочу бачити - відводжу очі”, виникає ФО, яка, зберігаючи деяку первинність значення, переосмислюється й набуває іншого значення. Друге значення мотивоване першим, однак його витлумачення є розмитим: навмисне відволікати людину, намагатися iï обдурити 
можна за умови, якщо людина буквально не сприймає очима, не слідкує ними за ситуацією або взагалі утратила „зорову пильність”, уважність.

Схоже розуміння й такого фразеологізму як заплющувати очі, що означає ,1) навмисне не помічати чого-небудь, не звертати уваги на щось; 2) умерти". Задля того, щоб обірвати потік небажаної зорової інформації, людина заплющує очі. Тому сам процес уже буде характерним для ситуацій не лише візуального плану, а й інших, схожих своїм впливом на суб’ єкт сприйняття.

У ФО [aж] nim очі заливає (переважно зі словами працювати, трудитися) наявний результат дії, яка відбувається „дуже важко, з великим напруженням", вимагає від людського організму значних зусиль. Унаслідок важкої праці на лобі виступають крапельки поту, які в біологічному сенсі постають способом охолодження людського тіла, однак безпосередньо в очі піт потрапляти не може. Фразеологізм концентрує первісне значення i підсилює його можливістю від супротивного, тим самим підкреслюючи надмірну важкість певних дій.

Перш ніж вести мову про міміку обличчя загалом та окремих його компонентів, варто з'ясувати особливість використання мімічних дій у невербальній комунікації.

Особливу роль серед елементів невербальної поведінки відводять міміці. Обличчя $є$ найважливішою характеристикою фізичного вигляду людини. Завдяки кортикальному контролю людина має змогу управляти кожним окремим мускулом свого обличчя. Соціальне наслідування - одна 3 умов розвитку міміки - можливе саме в результаті їі довільної регуляції. Загалом соціалізація міміки здійснюється в результаті використання органічних проявів для дії на партнера і перетворення емоційних реакцій адекватно до ситуації. Суспільство може заохочувати вираз одних емоцій і засуджувати інші, може створювати „мову” міміки, що збагатила спонтанні виразні рухи. У зв’язку з цим ми говоримо про універсальні або специфічні мімічні знаки, про оконвенційні, або спонтанні, вирази обличчя. Звичайно міміку аналізують:

1) за лінією їі довільних і мимовільних компонентів;

2) на основі iii фізіологічних параметрів (тонус, сила, комбінація м’язових скорочень, симетрія - асиметрія, динаміка, амплітуда);

3) у соціальному і соціально-психологічному планах (міжкультурні типи виразів, що належать певній культурі, або прийняті в соціальній групі, або індивідуальний стиль);

4) у феноменологічному плані (,,топографія мімічного поля”): фрагментарний, диференціальний і цілісний аналіз міміки;

5) у термінах тих психічних явищ, яким певні мімічні знаки відповідають;

6) можна також здійснювати аналіз міміки, виходячи 3 тих враженьеталонів, що формуються у процесі сприйняття людиною мімічних картин, навколишніх людей. Актуальні образи-еталони передбачають ознаки, які не тільки характеризують модель, але є достатніми для iі пізнання. 
Усесторонній аналіз мімічних виразів дає інформацію про загальну „мімічну обдарованість” особистості, що розкривається через такі характеристики:

1) сильна - слабка; невизначена - красномовна; безладна, судомна, гармонійна міміка;

2) різноманітність мімічних картин, швидкість зміни мімічних формул, здатність передавати нюанси;

3) міміка стереотипна, індивідуальна.

Л. Сухаребський відзначає, що для розуміння мімічної різноманітності людини $є$ сенс розглядати як цілісну мімічну активність, так і часткову, пов'язану з діяльністю окремих її зон. Але не слід забувати, продовжує він, що окремі мімічні зони лоба, очей, рота діють як ланки єдиної цілісної системи $[2,32]$.

Цілісність, динамічність - головні характеристики міміки як елемента невербальної поведінки особистості. Тому за одиницю аналізу власне мімічного виразу повинна бути прийнята сукупність координованих рухів м'язів всієї особи. У багатьох дослідженнях показано, що пізнання емоцій залежить від участі всіх лицьових м'язів.

За одиницю аналізу лицьового виразу була прийнята складна мімічна ознака. На фізіологічному рівні вона передбачає ряд характеристик: напрям руху лицьових м'язів, відношення між рухами м'язів, інтенсивність, напруження м'язів людини. У феноменологічному плані мімічна ознака представляє: „брови підняті вгору, губи щільно стислі” і т. ін.

Складні мімічні ознаки є необхідними, постійними, але в той же час можуть входити у структуру міміки різних станів. У зв'язку з цим постійним і необхідним індикатором психічних станів виступатиме комплекс ознак міміки. Пропонована схема описів міміки шести емоційних станів (радість, гнів, страх, страждання, здивування, огида) будується з урахуванням цього принципу, що дозволяє знайти універсальні ознаки для певного типу станів, специфічні ознаки для певного типу станів, специфічні ознаки для кожного стану, неспецифічні, які набувають значення тільки в контексті з іншими ознаками.

Розглянемо стійкі сполучення, що називають мімічні реакції, дії, у яких беруть участь окремі частини обличчя (губи, рот, окремо вуха):

а) зуби: зуби скриплять; зиіпивши зуби; крізь зуби; показати зуби (роги, пазурі) тощо.

Фразеологізм зуби скриплять означає, що „хтось дуже розлючений, сповнений гніву, ненависті”. Підосновою вислову може бути те, що у стані розлючення, гніву поведінка і рухи є некерованими, спостерігається сильне збудження, яке виникає в результаті фрустрації або іншої причини, що так чи так подіяла на психіку і зазвичай пов'язана із незадоволеністю важливих для людини потреб. Це все $\epsilon$ характерним для стану афекту, власне, скрип зубами - властива йому фізіологічна неусвідомлена дія. 
Зуби як невід’ємна частина, складова ротової порожнини виконують багато функцій, однією з яких разом із губами є своєрідний захист рота від різних впливів, зазвичай негативних. Вислів крізь зуби означає „неохоче, невиразно, ледве розтуляючи рота; з незадоволенням", хоч первісно, можна припустити, утворився як характеристика дії, що присікається зубами: робити щось крізь зуби - захищати себе від стороннього небажаного впливу, утримуватися у висловлюваннях (буквально закривати рот зубами, щоб не промовити зайвого). 3 часом стійкий вислів набув іншої атрибуції і став називати дію, яка виконується суб'єктом неохоче, без задоволення, і про це він змушений мовчати, знову ж таки стримувати себе зубами. Схожим до цього фразеологізму є вислів зиіпивши зуби, що також використовується для характеристики почуттів людини через ротовий апарат та зуби. Людина стримує свої почуття, напруживши всі сили, а зуби постають як своєрідний бар'єр і захист, аби стриматися;

б) губи: надувати губи / надути губи; квасити губи; розквасити губи; лизати губи (губки) та інші.

Губи є більш активним органом, ніж зуби, звичайно за такої умови вони можуть виражати і більший спектр емоцій. Так, ФО надувати губи перше своє значення має від самої мімічної дії, а саме вона означає „гніваючись, ображаючись і т. ін., надавати обличчю незадоволеного вигляду”. Збільшуючи розмір губ, рухаючи ними в момент емоційного напруження, людина намагається допомогти собі контролювати свій стан. Друге значення - "виражати зверхність, поважність, пишатися, зазнаватися" - не має буквального тлумачення через біхевіористичну формулу „стимул - реакція", хоч і є зрозумілим, певною мірою мотивованим;

в) ніс: крутити носом; совати [свого] носа; тримати ніс (носа) за вітром (по вітру); вернути ніс (носа) і т. ін.

Фразеологізм крутити носом означає „триматися на відстані, відвертатися від когось, чогось 3 певних причин". Людський ніс менш розвинений, ніж у тварин, хоч має не менш складну організацію та виконує важливу функцію. У процесі сприйняття нюховими центрами інформації про об'єкт навколишньої дійсності виникає не лише певний образ зі своїми характерними ознаками, а й формується певне ставлення до нього. Отже, така властивість органа нюху як одного з органів чуттів дає можливість припустити, що ФО крутити носом первинно означало „відвернути ніс від людини або іншого об'єкта, що мав специфічний, стійкий, можливо, навіть неприємний запах, і з огляду на це триматися від нього на відстані”. 3 часом значення фразеологізму стало більш узагальненим і сам запах постає основним показником в оцінці ситуації спілкування. Однак не варто недооцінювати значення органа нюху під час комунікації: учені неодноразово заявляли, що ніс допомагає людині визначитися у своєму ставленні до інших людей, виявляти прихильність, недовіру, неприязнь, любов тощо; 
г) вуха: вуха позаростали; вуха насторожилися; наставляти вуха (вухо) тощо.

ФО вуха насторожилися означає „хто-небудь почав прислухатися, став зосередженим, напружено уважним", що є своєрідною фіксацією рефлексивного руху. За умов, коли звуковий сигнал досягає порогу відчуття, звуковий стимул набуває для об'єкта особистісного значення, людина здійснює рефлексивний рух головою, ніби наближаючи вухо до джерела звуку. Тим самим збільшується концентрація уваги, підвищується м'язовий тонус, людина перебуває в напруженому стані так довго, на скільки особистісно важливою є для неї звукова інформація;

г) рот, горло: аж піна з рота (на губах) скаче; кривити рот (губи, уста); набирати води в рот; клубок підкочується до горла та інші.

Органами, які безпосередньо беруть участь в утворенні звуків мовлення, є ротова порожнина, горло, язик та ін. Тому їх ситуативний стан може повідомляти про самопрезентацію людини, інтенсивність їі дій, виконувати емотивну функцію. ФО клубок підкочується до горла означає, що „комунебудь спазми стискають горло від сильного хвилювання, переживання”.

У психології немає однозначного погляду на функціонування та виникнення емоцій (так званих елементарних емоцій) у зв'язку з органічними процесами. Згідно з основними теоріями, першопричинами виникнення емоційних станів є зміни фізіологічного характеру, які відбуваються в організмі. Виникаючи під впливом зовнішніх або внутрішніх стимулів, вони потім відображаються в голові людини через систему зворотних нервових зв'язків та породжують відчуття певного емоційного тону. Анатомо-фізіологічною основою цих емоцій є лімбічні структури ЦНС, а також процеси, які протікають у таламусі та гіпоталамусі. Перший етап - сприйняття впливу емоціогенного стимулу (зорові, слухові стимули, що викликають стан хвилювання, занепокоєння тощо). Другий етап - переробка центральними структурами головного мозку імпульсів, які поступають від рецепторів, з одночасною передачею збудження в кору головного мозку та до інших тілесних органів (інакше кажучи, це своєрідне „перекодування” сприйнятої інформації на „мову мозку”). Останній етап має двоякий характер: по-перше, це виникнення емоційного стану, який переживається суб'єктивно (індивідуальний рівень переживань, сила дії стимулу, що і виражається в особистісному сприйнятті фрустраційної ситуації); по-друге, це поява нервово-м'язової реакції організму (безпосередньо спазми в горлі, відчуття в ньому своєрідного клубка, який заважає дихати і вільно говорити). Отже, клубок біля горла є відповіддю м'язів на вплив певного емоціогенного чинника.

До третьої групи належать емоційно насичені фразеологізми на позначення мімічних дій, що виражають певні фізіологічні зміни рис обличчя: аж з виду перемінився; [аж] мінитися на лищуі (в лищуі; на обличчі); зайтися рум'янцем; з кам'яним лицем; кидає в краску; кисла міна; скривити робити кислу міну тощо. 
Емоційний стан характеризується не тільки внутрішніми переживаннями, а й зовнішніми проявами. Паралінгвістичні компоненти набувають довершенішого звучання, повної експресивності в мовних знаках. Значна кількість ФО є в основі свого значення багатий життєвий досвід, висновок емпіричного пізнання світу. Стійкий вислів [аж] мінитися на лиці (в лиці; на обличчі) означає „набирати іншого виразу обличчя у зв’язку з переживаннями (злістю, радістю)". Отже, дія зовнішнього або внутрішнього стимулу сприяє суб'єктивності переживання конфліктної або фрустраційної ситуації, а також певної відповіді на неї організму. Зі ФО важко встановити, які саме зміни виразу обличчя можна спостерігати, однак факт зміни має в собі глибинний сенс, тобто фразеологізм є змістовно насиченим. Натомість ФО кидає в краску; зайтися рум'янцем визначають характер якісних змін з людиною внаслідок впливу зовнішніх чи внутрішніх чинників. Обличчя людини червоніє внаслідок того, що серце починає працювати швидше через підвищення рівня адреналіну в крові, капіляри шкіри наливаються кров'ю. До такого стану призводить надмірне хвилювання, збудження, почуття сорому, збентеження. Отже, зміст фразеологізму цілком закономірний та виправданий.

Проведене дослідження переконливо свідчить, що паралінгвістична фразеологія - це солідна група усталених конструкцій, цікава як з позиції семантики, так і з позиції етнопсихології, національного менталітету того чи того народу. Мімічні фразеологічні одиниці диференціюються відповідно до особливостей погляду, виразу очей, мімічних реакцій, у яких беруть участь окремі частини обличчя (губи, рот, вуха), а також дій, що виражають певні фізіологічні зміни рис обличчя.

\section{Література}

1. Словник фразеологізмів української мови [уклад. В. М. Білоноженко та ін.]. К.: Наукова думка, 2003. - 1104 с.

2. Сухаребский Л. М. Улыбка, настроение, здоровье / Л. М. Сухаребский. - М.: Медицина, 1964. $-48 \mathrm{c}$.

3. Урысон Е. В. Синонимический ряд лексемы взгляда / Е. В. Урысон / под ред. Ю. Д. Апресяна // Новый объяснительный словарь синонимов русского языка. - М.: Прогресс, 1997. - 752 с. 